\title{
EFFECTIVENESS OF WINTER WHEAT VARIETIES OF WORLD SELECTION IN SOUTH URAL
}

\section{ЭФФЕКТИВНОСТЬ СОРТОВ ОЗИМОЙ ПШЕНИЦЫ МИРОВОЙ СЕЛЕКЦИИ НА ЮЖНОМ УРАЛЕ}

\author{
A. Glinushkin, Candidate of Biological Sciences ${ }^{1}$ \\ А.П. Глинушкин, кандидат биологических наук \\ E-mail: glinale@gmail.com, Phone: +7 (912) 359-00-18 \\ O. Beloshapkina, Doctor of Agricultural Sciences ${ }^{2}$ \\ О.О. Белошапкина, доктор сельскохозяйственных наук \\ S. Plygun, Candidate of Agricultural Sciences ${ }^{3}$ \\ С.А. Плыгун, кандидат сельскохозяйственных наук \\ N. Nikolaev, Researcher ${ }^{1}$ \\ Н.А. Николаев, научный сотрудник \\ T. Mishenina, G. Myasnyankina, V. Lukyantsev, S. Dushkin, \\ E. Karamatova, A. Vasilyeva, N. Grigorieva, Post-graduate students ${ }^{1}$ \\ Т.А. Мишенина, Г.А. Мяснянкина, В.С. Лукъянцев, С.А. Душкин, \\ Е.Н. Караматова, А.С. Васильева, Н.А. Григорьева, соискатели \\ A. Solovykh, Candidate of Biological Sciences ${ }^{1}$ \\ A.A. Соловых, кандидат биологических наук \\ A. Rayov, Candidate of Agricultural Sciences ${ }^{1}$ \\ A.А. Райов, кандидат сельскохозяйственных наук \\ ${ }^{1}$ Orenburg State Agrarian University, Orenburg, Russia \\ Оренбургский государственный аграрный университет, Оренбург, Россия \\ ${ }^{2}$ Russian State Agrarian University - Moscow Agricultural Academy \\ named after K.A. Timiryazev, Moscow, Russia \\ Российский государственный аграрный университет - MCXА \\ имени К.А. Тимирязева \\ ${ }^{3}$ Orel State Agrarian University, Orel City, Russia \\ Орловский государственный аграрный университет, Орел, Россия
}

\begin{abstract}
Varieties of winter wheat of world selection were studied in the conditions of South Ural. The conducted researches showed that in conditions of a steppe zone of South Ural possibly receiving more than 5,0 t of grain of winter wheat. For a steppe zone of South Ural four effective grades of winter wheat are defined: Kolos 47, Nika, KNIISH 756, Mironovskaya 64.

\section{АННОТАЦИЯ}

Сорта озимой пшеницы мировой селекции были изучены в условиях Южного Урала. Проведенные исследования показали, что в условиях степной зоны Южного Урала возможно получение более 5,0 т зерна озимой пшеницы. Для степной зоны Южного Урала определены четыре эффрективных сорта озимой пшеницы: Колос 47, Ника, КНИИСХ 756, Мироновская 64.
\end{abstract}




\section{KEY WORDS}

Wheat; Varieties; Disease; Puccinia recondite; Productivity; Full-scale mass of grain.

\section{КЛЮЧЕВЫЕ СЛОВА}

Пшеница; Сорта; Болезни; Puccinia recondite; Урожайность; Натурная масса зерна.

Озимая пшеница привлекательная культура в условиях степной зоны Южного Урала [1]. Потенциал, продуктивности её высок, но на практике труднодостижим, по ряду причин $[2,3,4]$. Фитосанитарное состояние, его мониторинг, контроль - сложные задачи, наиболее эффективное решение возможно интегрировано $[5,6,7,8]$, эфрективны технологии двойного использования [9], однако первым выступает селекционный метод [10]. Оценка сортов, селекционных линий, проводимая в условиях предполагаемого использования сортов важный практический элемент, как для корректировки работы селекционеров, таки для службы защиты растений. Подробный анализ таких исследований позволяет использовать материал и в качестве, матрицы для прогнозирования.

Цель работы - определить эффективный потенциал сортообразцов коллекции озимой пшеницы в условиях степной зоны Южного Урала по хозяйственно ценным и другим показателям.

\section{МАТЕРИАЛ И МЕТОДИКА ИССЛЕДОВАНИЙ}

250 сортообразцов озимой пшеницы из мировой коллекции ВНИИР имени Н.И. Вавилова изучали по ряду параметров в 2006-2007 гг. на опытном поле Оренбургского ГАУ, в коллекционном питомнике, в 4-х польном селекционном севообороте, растения отбирались с 1-й повторности на делянках площадью $2 \mathrm{~m}^{2}$. Агротехника - общепринятая для данной зоны, норма высева 4,0 млн. всхожих семян на 1 га, почва - чернозём южный.

Для всестороннего анализа отобрано 154 сортообразца. Представленные результаты фитосанитарного обследования коллекционных сортообразцов провели на естественном инфекционном фоне в период развития грибных, бактериальных и вирусных заболеваний. Массово были представлены: Ржавчина бурая (Puccinia recordita Rob. Ex Desm f. sp. triticl); Мучнистая роса (Blumeria graminis (DC.) Speer f. sp. tritici Marchal.); Кончиковый бактериоз (Xantomonas translucens) [8, 9, 10]; встречались вирусоподобные симптомы подходящие под описание возбудителей: Вируса полосатой мозаики пшеницы Wheat streak mosaic virus (WSMV); Русской мозаики озимой пшеницы Russian wheat mosaic (RWMV); Мозаики злаков Triticum mosaic virus (TrMV); Желтой карликовости ячменя Barley yellow dwarf virus (BYDV); Штриховатой мозаики костра Brome streak mosaic virus (BrSMV); Мозаики костреца Bromegrass mosaic virus (BrMV); Штриховатой мозаики ячменя Barley stripe mosaic virus (BSMV) и др. [3].

Распространенность болезней и идентификацию возбудителей проводили следующими методами: визуальной диагностики, методами рулонным и влажной камеры, микробиологическим, микроскопическим, молекулярно-генетическим [3]. Стандартными методами определяли энергию прорастания и всхожесть семян, натуру, урожай. В силу ограниченного объема выборки, отбор растений проводили; осенью и ранней весной в фазах кущения-трубкования с площади 0,25 м² ; позднее с площади $0,05 \mathrm{~m}^{2}$ (20 cм, на 22,5 cм). Урожайность учитывали селекционным комбайном Sampo 2100. Собранное зерно исследовалось лабораторно, где определялась натурная масса зерна и другие показатели.

\section{РЕЗУЛЬТАТЫ И ОБСУЖДЕНИЕ}

Многомерны фракторы, от которых зависит эфффективность производства озимой пшеницы. В таблице 1 мы представили основные для нас, полученные в фразу 
массового цветения сортообразцов, а также элементы эффективности производства (количество растений учета, урожайность и натурную массу зерна).

Для охвата большего круга вредных организмов, мы совместили показатели повреждения возбудителями болезней озимой пшеницы и вредителями (грызущими и сосущими) назвали - смешанным поражением вредными организмами (сортообразцы растения, которых не имели признаков повреждения вредителями и возбудителями болезней обозначены числом ), другие обозначены числом 1).

Бактериозы и вирозы, также были объедены в один показатель, и сохранена степень их проявления выраженная в процентах, повреждения органов растений на которых они идентифицировались.

Кончиковый бактериоз, отмечался как по распространенности (рассчитывалась по стандартной методике), так и по размеру проявления на листьях (выраженному в сантиметрах).

Мучнистая роса и ржавчина, рассчитывались по общепризнанным фрормулам. Важнейшие показатели, определяющие эфреективность производства озимой пшеницы: урожайность зерна в центнерах (0,1 тонны) на 1 га; натурная масса зерна в граммах на 1 литр, число 0 в этих показателях означает - отсутствие данных.

В результате проведенных исследований, анализ таблицы по урожайности (ц/га, точно или в вариации, в скобках указывается место происхождения), позволяет выделить наиболее перспективные сорта: Chieftain (Англия) - 41,02; Ресурс (Безенчук) - 42,75; Ермак (Зерноград) - 42,2; Зарница (Зерноград) - 45,7; Зерноградка 11 (Зерноград) - 42,9; Ростовчанка 3 (Зерноград) - 42,8; Дон 93 (Зерноград) - 43,29; Дон 85 (Зерноград) - 42,66; Дон 95 (Зерноград) - 47,34; Быстрица (Краснодар) - 40,76-43,33; Колос 47 (Краснодар) - 54,78; Офрелия (Краснодар) - 45,78; Ника Кубани (Краснодар) 56,92; 145 Р2 (Краснодар) - 41,96-43,64; КНИИСХ 756 (Краснодар) - 54,16; Наследница 63385 (Краснодар) - 49,41; Пионерская 32 (Оренбург) - 40,06-42,09; Безор 3 (Оренбург) - 40,05; Августа (Ростов) - 41,72; Донская 50 (Ростов) - 41,57; ТАМ 107 (США) - 47,82; KS90WGRC10 (США) - 46,51; TCEP 9038 (США) - 42,08; McNair 1587 (США) - 41,63; Мироновская 31 (Украина) - 43,24; Мироновская 33 (Украина) - 45,66; Мироновская 64 (Украина) - 51,05; Мироновская 34 (Украина) - 40,75.

По нашему мнению, потенциально перспективными следует признать сорта с урожайностью более 50 ц/га: Колос 47 (Краснодар) - 54,78; Ника Кубани (Краснодар) 56,92; КНИИСХ 756 (Краснодар) - 54,16; Мироновская 64 (Украина) - 51,05. Происхождение трех из них, Российское и 1 сорт Украинской селекции. Тем не менее, перспективы работ с селекцией озимой пшеницы открыто признают и мировые гиганты (корпорации). Лидером в области культуры озимой краснозерной пшеницы в мире признается DuPont Pioneer. Monsanto была готова вывести на рынок биотехнологическую пшеницу, устойчивую к гербициду, в 2004 г., но отложила это из-за ряда причин. В 2009 г. Monsanto объявила о возобновлении работы с пшеницей. Dow AgroSciences, Syngenta, и ряд других компаний также ищут способы улучшения пшеницы биотехнологическими методами [5].

\section{ВЫВОдЫ}

Проведенные исследования показали эффрективность озимой пшеницы. Мы считаем перспективным вести работу на селекцию озимой пшеницы в условиях степной зоны Южного Урала с урожайностью более 50 ц/га. Для получения результатов по урожайности необходимо всестороннее изучение четырех сортов: Колос 47 (Краснодар) - 54,78; Ника Кубани (Краснодар) - 56,92; КНИИСХ 756 (Краснодар) - 54,16; Мироновская 64 (Украина) - 51,05 ц/га соответственно. Потерю эффрективности производства озимой пшеницы от проявления вредных организмов, необходимо изучать на разно уровневых принципах и более детально с учетом систем: патоген-пшеница, вредитель-пшеница или вредные организмы-пшеница. 
Таблица 1 - Результаты по показателям сортообразцов озимой пшеницы

\begin{tabular}{|c|c|c|c|c|c|c|c|c|c|c|c|c|c|c|c|c|c|}
\hline \multirow{2}{*}{$\begin{array}{c}\text { № } \\
\text { делянки }\end{array}$} & \multirow{2}{*}{$\begin{array}{c}\text { № } \\
\text { по } \\
\text { отчету }\end{array}$} & \multirow{2}{*}{ Сортообразцы } & \multirow{2}{*}{ Происхождение } & \multirow{2}{*}{$\begin{array}{c}\text { Урожайность, } \\
\text { ц/га }\end{array}$} & \multirow{2}{*}{$\begin{array}{l}\text { Натурная } \\
\text { масса, г/л }\end{array}$} & \multirow{2}{*}{$\begin{array}{c}\text { Растений } \\
\text { в анализе } \\
\text {, шт. }\end{array}$} & \multicolumn{3}{|c|}{ Кустистость одного растения } & \multicolumn{2}{|c|}{ Ржавчина } & \multicolumn{2}{|c|}{$\begin{array}{c}\text { Мучнистая } \\
\text { роса }\end{array}$} & \multicolumn{2}{|c|}{$\begin{array}{l}\text { Кончиковый } \\
\text { бактериоз }\end{array}$} & \multirow{2}{*}{\begin{tabular}{c} 
Бактериозы \\
и вирозы \\
\hdashline P, \%
\end{tabular}} & \multirow{2}{*}{$\begin{array}{c}\text { Смешанное } \\
\text { поражение } \\
\text { вредными } \\
\text { организмами }\end{array}$} \\
\hline & & & & & & & общая & $\begin{array}{c}\text { продуктивна } \\
9\end{array}$ & непродуктивная & $P, \%$ & $R, \%$ & $P, \%$ & $R, \%$ & $\mathrm{P}, \%$ & $\mathrm{R}, \mathrm{CM}$ & & \\
\hline 431 & 148 & Willi & Австрия & 0 & 0 & 2 & 34 & 33,5 & 0,5 & 100 & 5 & 0 & 0 & 36 & 1 & 0 & 1 \\
\hline 441 & 44 & Leopold & Австрия & 0 & 0 & 8 & 7,1 & 4 & 3,1 & 0 & 0 & 0 & 0 & 75 & 1 & 0 & 1 \\
\hline 447 & 30 & Livius & Австрия & 0 & 0 & 3 & 10,2 & 7,1 & 3,1 & 50 & 15 & 0 & 0 & 0 & 0 & 0 & 1 \\
\hline 478 & 66 & Georg & Австрия & 24,7 & 0 & 5 & 16,2 & 8,4 & 7,8 & 75 & 5 & 0 & 0 & 75 & 1 & 50 & 0 \\
\hline 541 & 74 & Hubertus & Австрия & 0 & 0 & 6 & 4,5 & 2,7 & 1,8 & 100 & 2 & 100 & 5 & 0 & 0 & 0 & 1 \\
\hline 494 & 63 & Горянка & Адыгея & 0 & 741 & 6 & 10 & 4,5 & 5,5 & 75 & 8 & 25 & 0 & 0 & 0 & 50 & 0 \\
\hline 516 & 82 & $\begin{array}{c}\text { Наследница } \\
63103\end{array}$ & Адыгея & 27,43 & 748 & 8 & 10,8 & 6,4 & 4,4 & 0 & 0 & 0 & 0 & 100 & 0,75 & 0 & 1 \\
\hline 325 & 149 & Maris Huntsman & Ӓнглия & 26,08 & 724 & 4 & 7,8 & 4,5 & 3,3 & 100 & 6,5 & 0 & 0 & 17 & 0,1 & 25 & 1 \\
\hline 367 & 7 & Alert & Англия & 35,58 & 742 & 10 & 7 & 2,9 & 4,1 & 50 & 2,5 & 0 & 0 & 75 & 0,2 & 25 & 0 \\
\hline 377 & 27 & Maris Hurtsman & Англия & 32,43 & 722 & 6 & 9,5 & 3,3 & 6,2 & 100 & 25 & 0 & 0 & 100 & 0,5 & 0 & 1 \\
\hline 409 & 136 & Chieftain & Англия & 41,02 & 745 & 8 & 8,8 & 4,3 & 4,5 & 56 & 1 & 0 & 0 & 11 & 0,1 & 22 & 1 \\
\hline 410 & 107 & Viscount & Англия & 38,71 & 727 & 5 & 9,8 & 7 & 2,8 & 100 & 6,5 & 0 & 0 & 0 & 0 & 0 & 1 \\
\hline 425 & 169 & Encore & Англия & 0 & 0 & 10 & 6,4 & 2,8 & 3,6 & 25 & 0,5 & 0 & 0 & 25 & 1 & 100 & 1 \\
\hline 448 & 79 & Sarasen & Англия & 32,33 & 722 & 4 & 6,3 & 3 & 3,3 & 50 & 0,5 & 0 & 0 & 75 & 2,5 & 50 & 0 \\
\hline 470 & 178 & Rialto & Ӓнглия & 0 & 0 & 1 & 32 & 25 & 7 & 2,3 & 0 & 0 & 0 & 0 & 0 & 33 & 1 \\
\hline 485 & 119 & Mandat & Англия & 0 & 0 & 5 & 8,6 & 7,2 & 1,4 & 100 & 5 & 0 & 0 & 50 & 0 & 0 & 1 \\
\hline 512 & 174 & Maris Huntsman & Англия & 35,38 & 720 & 5 & 11,4 & 6,2 & 5,2 & 75 & 3,5 & 0 & 0 & 25 & 0,25 & 100 & 0 \\
\hline 299 & 92 & Светоч & Безенчук & 26,44 & 718 & 7 & 5,6 & 3,7 & 1,9 & 50 & 32,5 & 0 & 0 & 0 & 0 & 50 & 1 \\
\hline 320 & 154 & Pecypc & Безенчук & 42,75 & 736 & 10 & 7,6 & 2,8 & 4,8 & 100 & 29,5 & 0 & 0 & 100 & 0 & 0 & 1 \\
\hline 301 & 60 & Сплав & Владимир & 25,86 & 732 & 8 & 5,4 & 2 & 3,4 & 25 & 0,6 & 0 & 0 & 25 & 1 & 25 & 0 \\
\hline 297 & 115 & Казачок & Волгоград & 25,55 & 768 & 10 & 5,7 & 3,4 & 2,3 & 100 & 7,5 & 0 & 0 & 50 & 0 & 0 & 0 \\
\hline 315 & 134 & Горная поляна & Волгоград & 23,05 & 746 & 4 & 10,8 & 6,8 & 4 & 84 & 1,5 & 16 & 0,7 & 66 & 1,3 & 0 & 1 \\
\hline 542 & 96 & Волга-Дон & Волгоград & 28,33 & 759 & 8 & 5 & 2 & 3 & 75 & 3,8 & 0 & 0 & 25 & 0,25 & 0 & 1 \\
\hline 351 & 4 & Лютесценс 310 & Воронеж & 37,86 & 724 & 9 & 7,5 & 3,1 & 4,4 & 50 & 0,7 & 0 & 0 & 25 & 0,3 & 0 & 0 \\
\hline 364 & 65 & Лютесценс 321 & Воронеж & 38,1 & 740 & 4 & 15,5 & 5 & 10,5 & 75 & 1 & 0 & 0 & 50 & 0 & 25 & 1 \\
\hline 428 & 83 & Roti & Германия & 25,23 & 698 & 7 & 11 & 7,7 & 3,3 & 0 & 0 & 0 & 0 & 50 & 0,4 & 50 & 1 \\
\hline 479 & 147 & Taras & Германия & 23,49 & 698 & 11 & 5,6 & 3,5 & 2,1 & 50 & 5 & 0 & 0 & 50 & 0,5 & 50 & 1 \\
\hline 0 & 137 & Ермак & Зерноград & 42,2 & 743 & 9 & 6,2 & 3 & 3,2 & 67 & 1,6 & 33 & 0,8 & 0 & 0 & 17 & 0 \\
\hline 0 & 179 & Зарница & Зерноград & 45,7 & 764 & 10 & 5,1 & 2,9 & 2,2 & 33 & 1,1 & 0 & 0 & 0 & 0 & 83 & 1 \\
\hline 0 & 31 & Зерноградка 11 & Зерноград & 42,9 & 770 & 2 & 8,5 & 5,5 & 3 & 0 & 0 & 0 & 0 & 0 & 0 & 0 & 1 \\
\hline 0 & 161 & Ростовчанка 3 & Зерноград & 42,8 & 774 & 8 & 8,7 & 6,6 & 2,1 & 100 & 10 & 0 & 0 & 0 & 0 & 0 & 1 \\
\hline 331 & 3 & Дон 93 & Зерноград & 39,21 & 742 & 8 & 5,7 & 2,6 & 3,1 & 100 & 0,7 & 25 & 10 & 50 & 1,5 & 25 & 0 \\
\hline 558 & 153 & Дон 93 & Зерноград & 43,29 & 746 & 10 & 5,7 & 2,2 & 3,5 & 100 & 5 & 0 & 0 & 75 & 1,6 & 75 & 1 \\
\hline 560 & 32 & Дон 85 & Зерноград & 42,66 & 738 & 3 & 5,9 & 3,6 & 2,3 & 0 & 0 & 0 & 0 & 25 & 0 & 0 & 1 \\
\hline 561 & 50 & Дон 95 & Зерноград & 47,34 & 768 & 10 & 8,6 & 3,2 & 5,4 & 100 & 10 & 0 & 0 & 50 & 0 & 0 & 0 \\
\hline 300 & 56 & Селянка & Краснодар & 33,04 & 742 & 7 & 7,4 & 4,7 & 2,7 & 0 & 0 & 0 & 0 & 25 & 1 & 0 & 0 \\
\hline 303 & 90 & Лютесценс 660 & Краснодар & 37,71 & 736 & 8 & 7,2 & 3,8 & 3,4 & 50 & 7,5 & 0 & 0 & 0 & 0 & 50 & 1 \\
\hline 310 & 97 & Княжна & Краснодар & 32,08 & 726 & 7 & 10,1 & 4,8 & 5,3 & 50 & 1 & 16 & 0 & 16 & 0,2 & 50 & 1 \\
\hline
\end{tabular}




\begin{tabular}{|c|c|c|c|c|c|c|c|c|c|c|c|c|c|c|c|c|c|}
\hline 313 & 135 & $\begin{array}{c}\text { Краснодарская } \\
90\end{array}$ & Краснодар & 31,8 & 758 & 10 & 8,7 & 4,2 & 4,5 & 100 & 8,8 & 0 & 0 & 16 & 0,2 & 0 & 1 \\
\hline 316 & 45 & $145 \mathrm{P} 2$ & Краснодар & 43,64 & 768 & 6 & 5 & 2,2 & 2,8 & 50 & 0 & 0 & 0 & 0 & 0 & 0 & 1 \\
\hline 317 & 12 & $146 \mathrm{P} 6$ & Краснодар & 37,17 & 738 & 10 & 5,2 & 2,3 & 2,9 & 75 & 10 & 0 & 0 & 100 & 0,5 & 0 & 0 \\
\hline 323 & 18 & $177 \mathrm{P} 2$ & Краснодар & 29,2 & 742 & 10 & 9,8 & 4,6 & 5,2 & 0 & 0 & 25 & 10 & 0 & 0 & 25 & 1 \\
\hline 326 & 36 & Быстрица & Краснодар & 35,25 & 744 & 2 & 8 & 4 & 4 & 100 & 5 & 0 & 0 & 0 & 0 & 0 & 1 \\
\hline 342 & 168 & Верна & Краснодар & 38,18 & 754 & 10 & 6,3 & 3,3 & 3 & 50 & 1 & 0 & 0 & 50 & 1,5 & 100 & 0 \\
\hline 347 & 155 & $177 \mathrm{P} 2$ & Краснодар & 39,77 & 738 & 8 & 11,3 & 5,5 & 5,8 & 17 & 0,3 & 50 & 3,2 & 50 & 1 & 16 & 0 \\
\hline 360 & 53 & Дея & Краснодар & 36,83 & 762 & 5 & 10,2 & 6 & 4,2 & 25 & 3,8 & 50 & 11,3 & 25 & 0 & 50 & 0 \\
\hline 371 & 163 & Княжна & Краснодар & 32,61 & 716 & 10 & 11,4 & 7,8 & 3,6 & 100 & 15 & 80 & 2,2 & 17 & 0,5 & 0 & 1 \\
\hline 385 & 8 & Хуторянка & Краснодар & 25,36 & 727 & 7 & 7,6 & 3,3 & 4,3 & 50 & 10 & 0 & 0 & 50 & 1 & 50 & 0 \\
\hline 393 & 146 & Быстрица & Краснодар & 40,76 & 744 & 3 & 13,7 & 6,7 & 7 & 83 & 1 & 100 & 0 & 16 & 0,2 & 17 & 1 \\
\hline 402 & 156 & $193 \mathrm{P} 1$ & Краснодар & 39,68 & 732 & 10 & ${ }^{7}$ & 4,9 & 2,1 & 83 & 25 & 0 & 0 & 16 & 0 & 16 & 0 \\
\hline 404 & 28 & КНИИСХ 8 & Краснодар & 39,32 & 762 & 8 & 7,2 & 4,6 & 2,6 & 100 & 7,8 & 0 & 0 & 0 & 0 & 0 & 0 \\
\hline 483 & 142 & Быстрица & Краснодар & 43,33 & 760 & 7 & 5,4 & 2,4 & 3 & 75 & 4,5 & 0 & 0 & 0 & 0 & 0 & 0 \\
\hline 491 & 166 & Вольница & Краснодар & 33,9 & 744 & 7 & 6,4 & 4,1 & 2,3 & 100 & 6 & 0 & 0 & 25 & 1,3 & 75 & 0 \\
\hline 504 & 89 & Колос 47 & Краснодар & 54,78 & 746 & 5 & 13,4 & 10,4 & 3 & 0 & 0 & 0 & 0 & 0 & 0 & 100 & 1 \\
\hline 505 & 165 & $193 \mathrm{P} 1$ & Краснодар & 0 & 0 & 6 & 5,2 & 2,7 & 2,5 & 83 & 3,2 & 17 & 0,2 & 17 & 0 & 67 & 1 \\
\hline 506 & 91 & Офелия & Краснодар & 45,78 & 728 & 8 & 8,2 & 3,9 & 4,3 & 75 & 8,8 & 0 & 0 & 25 & 0,2 & 0 & 1 \\
\hline 515 & 73 & Ника Кубани & Краснодар & 56,92 & 0 & 7 & 7,5 & 5,1 & 2,4 & 100 & 5 & 0 & 0 & 0 & 0 & 0 & 0 \\
\hline 517 & 47 & $145 \mathrm{P} 2$ & Краснодар & 41,96 & 774 & 6 & 9,6 & 4,8 & 4,8 & 0 & 0 & 0 & 0 & 75 & 0 & 100 & 1 \\
\hline 519 & 84 & $146 \mathrm{P} 6$ & Краснодар & 0 & 741 & 5 & 10,6 & 5,4 & 5,2 & 50 & 7,5 & 0 & 0 & 0 & 0 & 50 & 1 \\
\hline 534 & 175 & $193 \mathrm{P3}$ & Краснодар & 0 & 728 & 10 & 6,2 & 2,4 & 3,9 & 0 & 0 & 0 & 0 & 0 & 0 & 100 & 1 \\
\hline 535 & 158 & Зимородок & Краснодар & 37,16 & 710 & 7 & 5,8 & 3,3 & 2,4 & 83 & 5,5 & 0 & 0 & 0 & 0 & 0 & 1 \\
\hline 538 & 19 & КНИИСХ 756 & Краснодар & 54,16 & 705 & 9 & 4,6 & 2,3 & 2,3 & 75 & 1,5 & 0 & 0 & 0 & 0 & 0 & 1 \\
\hline 548 & 176 & $\begin{array}{c}\text { Наследница } \\
63385\end{array}$ & Краснодар & 49,41 & 0 & 7 & 5,2 & 3,1 & 2,1 & 75 & 3,25 & 0 & 0 & 25 & 0,25 & 75 & 1 \\
\hline 353 & 126 & Криста & Латвия & 28,09 & 728 & 6 & 6,9 & 3,2 & 3,7 & 32 & 1 & 0 & 0 & 100 & 1,7 & 0 & 1 \\
\hline 406 & 37 & Московская 39 & Москва & 36,85 & 754 & 5 & 8 & 5,2 & 2,8 & 100 & 1 & 0 & 0 & 50 & 0 & 0 & 1 \\
\hline 426 & 162 & Bersy & Нидерланды & 38,94 & 760 & 7 & 11,6 & 7,7 & 3,9 & 100 & 2,1 & 0 & 0 & 17 & 0,8 & 0 & 1 \\
\hline 502 & 61 & Avir & Нидерланды & 23,33 & 0 & 3 & 16 & 9 & 7 & 100 & 40 & 0 & 0 & 25 & 1 & 0 & 0 \\
\hline 502 & 64 & Avir & Нидерланды & 23,33 & 0 & 8 & 3 & 2,9 & 0,1 & 50 & 1 & 0 & 0 & 0 & 0 & 50 & 0 \\
\hline 0 & 131 & $\begin{array}{c}\text { Оренбургская } \\
14\end{array}$ & Оренбург & 0 & 0 & 5 & 4,5 & 3,6 & 1,8 & 100 & 4 & 0 & 0 & 0 & 0 & 0 & 1 \\
\hline 0 & 150 & Маяк 267 & Oренбург & 0 & 0 & 10 & 9,3 & 2,7 & 6,6 & 100 & 10 & 0 & 0 & 0 & 0 & 100 & 1 \\
\hline 0 & 124 & $\begin{array}{l}\text { Оренбургская } \\
105\end{array}$ & Оренбург & 0 & 0 & 10 & 5,9 & 2,8 & 3,1 & 50 & 2,5 & 0 & 0 & 50 & 0,4 & 0 & 1 \\
\hline 0 & 105 & Пионерская 32 & Оренбург & 0 & 0 & 10 & 9,9 & 5,6 & 4,3 & 100 & 53 & 0 & 0 & 100 & 0 & 0 & 0 \\
\hline 338 & 93 & Пионерская 32 & Оренбург & 34,73 & 0 & 8 & 8,7 & 5,6 & 3,1 & 100 & 15 & 0 & 0 & 0 & 0 & 0 & 1 \\
\hline 340 & 120 & Безор 2 & Оренбург & 33,22 & 730 & 5 & 7,4 & 3,4 & 4 & 75 & 3,75 & 0 & 0 & 25 & 0 & 0 & 0 \\
\hline 310 & 104 & Пионерская 32 & Оренбург & 41,71 & 0 & 9 & 7,1 & 3,1 & 4 & 50 & 1 & 0 & 0 & 16 & 0,2 & 50 & 0 \\
\hline 311 & 76 & Пионерская 32 & Оренбург & 40,06 & 0 & 4 & 5,5 & 4,5 & 1 & 100 & & 0 & 0 & 25 & 0,2 & 75 & 0 \\
\hline 312 & 113 & Безор 3 & Оренбург & 40,05 & 742 & 10 & 8,5 & 4,1 & 4,4 & 100 & 15 & 0 & 0 & 100 & $\frac{1}{1}$ & 0 & 0 \\
\hline 337 & 85 & Пионерская 32 & Оренбург & 38,26 & 0 & 7 & 8,7 & 5,4 & 3,3 & 50 & 7,5 & 0 & 0 & 50 & 0,2 & 0 & 1 \\
\hline 343 & 6 & Безор 1 & Оренбург & 39,93 & 754 & 10 & 6,9 & 2,8 & 4,1 & 75 & 8,3 & 0 & 0 & 25 & 0,5 & 75 & 0 \\
\hline 361 & 16 & Пионерская 32 & Оренбург & 34,5 & 0 & 8 & 9,3 & 3 & 6,3 & 100 & 6,7 & 0 & 0 & 100 & 0,4 & 25 & 0 \\
\hline
\end{tabular}




\begin{tabular}{|c|c|c|c|c|c|c|c|c|c|c|c|c|c|c|c|c|c|}
\hline 362 & 145 & Пионерская 32 & Oренбург & 36,03 & 0 & 4 & 13,3 & 8,5 & 4,8 & 100 & 3,7 & 0 & 0 & 33 & 0,2 & 50 & 0 \\
\hline 427 & 17 & Пионерская 32 & Оренбург & 43,6 & 0 & 4 & 7,4 & 6,2 & 1,2 & 75 & 5 & 0 & 0 & 25 & 0,2 & 0 & 1 \\
\hline 556 & 10 & Пионерская 32 & Оренбург & 42,09 & 0 & 8 & 9,8 & 5,9 & 3,9 & 50 & 5 & 0 & 0 & 0 & 0 & 50 & 0 \\
\hline 362 & 77 & Kobra & Польша & 32,52 & 714 & 5 & 8,8 & 6,2 & 2,6 & 50 & & 0 & 0 & 25 & 0,1 & 100 & 0 \\
\hline 296 & 172 & $\begin{array}{c}\text { Северодонецка } \\
\text { я юбил }\end{array}$ & Ростов & 29,34 & 744 & 6 & 6 & 3,5 & 2,5 & 75 & 4,8 & 0 & 0 & 0 & 0 & 50 & 1 \\
\hline 314 & 111 & $\begin{array}{c}\text { Тарасовская } \\
\text { ост }\end{array}$ & Ростов & 23,02 & 744 & 10 & 3,3 & 1,4 & 1,9 & 50 & 0,5 & 0 & 0 & 0 & 0 & 50 & 1 \\
\hline 328 & 33 & $\begin{array}{c}\text { Росинка } \\
\text { тарасовская }\end{array}$ & Ростов & 29,68 & 728 & 2 & 11,5 & 6 & 5,5 & 75 & 5 & 25 & 10 & 0 & 0 & 25 & 1 \\
\hline 334 & 88 & $\begin{array}{c}\text { Родник } \\
\text { тарасовский }\end{array}$ & Ростов & 34,89 & 730 & 6 & 7,9 & 4,7 & 3,2 & 0 & 0 & 50 & 0 & 0 & 0 & 100 & 1 \\
\hline 344 & 94 & Августа & POCTOB & 41,72 & 712 & 11 & 5,4 & 2,8 & 2,6 & 0 & 0 & 0 & 0 & 50 & 0,6 & 50 & 1 \\
\hline 348 & 141 & $\begin{array}{c}\text { Северодонская } \\
14\end{array}$ & Ростов & 32 & 732 & 10 & 4,3 & 2,6 & 1,7 & 100 & 1 & 0 & 0 & 100 & 1 & 0 & 1 \\
\hline 354 & 5 & $\begin{array}{c}\text { Росинка } \\
\text { тарасовская }\end{array}$ & Ростов & 39,84 & 730 & 9 & 10,7 & 5 & 5,7 & 100 & 6,7 & 0 & 0 & 100 & 0,5 & 0 & 0 \\
\hline 355 & 167 & Донская 50 & Ростов & 41,57 & 720 & 9 & 8,6 & 4,8 & 3,8 & 75 & 3,4 & 0 & 0 & 0 & 0 & 75 & 0 \\
\hline 357 & 11 & Престиж & Ростов & 39,36 & 726 & 8 & 7 & 2,6 & 4,4 & 0 & 0 & 0 & 0 & 0 & 0 & 25 & 1 \\
\hline 396 & 114 & Августа & Ростов & 39,21 & 736 & 7 & 11,8 & 4,9 & 6,9 & 50 & 2,5 & 0 & 0 & 50 & 1,4 & 50 & 0 \\
\hline 544 & 143 & Aviesan & Румыния & 18,09 & 0 & 8 & 5,8 & 3 & 2,8 & 50 & 3,5 & 0 & 0 & 25 & 2,5 & 0 & 1 \\
\hline 356 & 49 & Поволжская 86 & Самара & 35,86 & 708 & 10 & 8,7 & 4,4 & 4,3 & 100 & 10 & 0 & 0 & 100 & 0 & 0 & 0 \\
\hline 302 & 34 & Губерния & Саратов & 30,39 & 736 & 2 & 12,5 & 4,5 & 8 & 60 & 5 & 0 & 0 & 20 & 0 & 0 & 1 \\
\hline 322 & 159 & $\begin{array}{c}\text { Лютесценс } 80- \\
08\end{array}$ & Саратов & 30,41 & 698 & 7 & 6,7 & 4,1 & 2,6 & 100 & 10 & 0 & 0 & 50 & 0,5 & 25 & 0 \\
\hline 341 & 125 & $\begin{array}{c}\text { Лютесценс 47- } \\
01\end{array}$ & Саратов & 26,84 & 724 & 10 & 6 & 2,3 & 3,7 & 100 & 26,3 & 0 & 0 & 25 & 0 & 0 & 1 \\
\hline 359 & 68 & $\begin{array}{c}\text { Лютесценс 31- } \\
98\end{array}$ & Саратов & 32,43 & 744 & 7 & 8,3 & 4,7 & 3,6 & 100 & 7,3 & 0 & 0 & 100 & 0,2 & 0 & 0 \\
\hline 318 & 108 & Norkan & СШ̈А & 28,14 & 750 & 6 & 5,8 & 3,2 & 2,6 & 100 & 6,5 & 0 & 0 & 100 & 1 & 0 & 0 \\
\hline 370 & 14 & KS89WGRC6 & СШ̈А & 32,46 & 740 & 10 & 4,5 & 2 & 2,5 & 50 & 1 & 50 & 8 & 50 & 0 & 0 & 1 \\
\hline 384 & 78 & TAM 107 & СЁA & 0 & 756 & 4 & 7,8 & 5,3 & 2,5 & 0 & 0 & 0 & 0 & 50 & 0,2 & 25 & 0 \\
\hline 391 & 13 & Chiefkan & СШ̈А & 31,54 & 776 & 4 & 14 & 7,8 & 6,2 & 100 & 90 & 50 & 20 & 0 & 0 & 0 & 0 \\
\hline 395 & 21 & TAM 107 & СШ̈A & 47,82 & 732 & 8 & 9,4 & 3,6 & 5,8 & 100 & 10 & 0 & 0 & 50 & 0 & 0 & 1 \\
\hline 403 & 22 & KS90WGRC 10 & СШेӒ & 46,51 & 752 & 8 & 8,4 & 4,5 & 3,9 & 75 & 0 & 0 & 0 & 50 & 0,7 & 0 & 1 \\
\hline 422 & 81 & Purcam & США & 39,13 & 734 & 4 & 12 & 10,5 & 1,5 & 100 & 0 & 25 & - & 0 & 0 & 25 & 0 \\
\hline 434 & 29 & Century & СШ̈А & 0 & 0 & 10 & 6,5 & 3,8 & 2,7 & 100 & 20 & 0 & 0 & 75 & 0,5 & 0 & 1 \\
\hline 449 & 23 & Andrews & СШ̈А & 0 & 0 & 6 & 7,8 & 5,8 & 2 & 100 & 1 & 0 & 0 & 0 & 0 & 0 & 1 \\
\hline 455 & 35 & TCEP 9038 & СШ̈А & 42,08 & 714 & 2 & 8 & 4,5 & 3,5 & 75 & 5 & 0 & 0 & 0 & 0 & 0 & 1 \\
\hline 458 & 2 & Susquehanna & СШ̈A & 24,61 & & 9 & 7,1 & 3 & 4,1 & 0 & 0 & 0 & 0 & 25 & 0,5 & 0 & 0 \\
\hline 463 & 86 & John & $\mathrm{C} \overline{\mathrm{WA}}$ & 20,32 & 712 & 5 & 9,8 & 5,6 & 4,2 & 0 & 0 & 0 & 0 & 0 & 0 & 100 & 1 \\
\hline 467 & 75 & Charmany & СШ̈А & 37,36 & 732 & 6 & 14,4 & 11,2 & 3,2 & 50 & 1,8 & 0 & 0 & 0 & 0 & 0 & 0 \\
\hline 501 & 20 & Mosa & США & 36,97 & 770 & 10 & 10,5 & 7 & 3,5 & 0 & 0 & 0 & 0 & 100 & 1 & 0 & 1 \\
\hline 514 & 112 & Nelson & СШ̈А & 41 & 712 & 9 & 7,8 & 2,1 & 5,7 & 100 & 0 & 0 & 0 & 50 & 0,55 & 0 & 1 \\
\hline 524 & 25 & KS89WGRC6 & СШ̈А & 32,12 & 748 & 12 & 6,4 & 2,8 & 3,6 & 75 & 15 & 0 & 0 & 100 & 1 & 25 & 1 \\
\hline 525 & 164 & Cherokee & СШ̈A & 0 & 0 & 10 & 5,9 & 2,8 & 3,1 & 33 & 1 & 0 & 0 & 17 & 0,5 & 33 & 0 \\
\hline 526 & 58 & Century & СШेА & 33,71 & 754 & 10 & 7,1 & 3,1 & 4 & 75 & 5 & 0 & 0 & 25 & 0 & 25 & 1 \\
\hline
\end{tabular}


Russian Journal of Agricultural and Socio-Economic Sciences, 4(16)

\begin{tabular}{|c|c|c|c|c|c|c|c|c|c|c|c|c|c|c|c|c|c|}
\hline 527 & 62 & Kay & США & 0 & 0 & 5 & 6,6 & 2,8 & 3,8 & 50 & 20 & 0 & 0 & 50 & 1 & 50 & 0 \\
\hline 540 & 122 & Cimarron & СШ̈А & 36,12 & 748 & 7 & 8,1 & 3,4 & 4,7 & 0 & 0 & 100 & 8 & 32 & 0,3 & 16 & 1 \\
\hline 550 & 99 & McNair 1587 & СШ̈А & 41,63 & 670 & 5 & 12,2 & 5 & 7,2 & 0 & 0 & 0 & 0 & 16 & 0 & 66 & 1 \\
\hline 305 & 123 & $\begin{array}{c}\text { Мироновская } \\
28\end{array}$ & Украина & 35,25 & 752 & 6 & 6 & 3,2 & 2,8 & 50 & 1,3 & 0 & 0 & 0 & 0 & 0 & 1 \\
\hline 305 & 171 & $\begin{array}{c}\text { Мироновская } \\
28 \\
\end{array}$ & Украина & 35,25 & 752 & 10 & 7,1 & 3 & 4,1 & 25 & 0,75 & 0 & 0 & 0 & 0 & 100 & 0 \\
\hline 329 & 110 & $\begin{array}{c}\text { Мироновская } \\
33\end{array}$ & Украина & 20,6 & 760 & 7 & 7,3 & 4,4 & 2,9 & 75 & 0,75 & 0 & 0 & 25 & 0 & 0 & 1 \\
\hline 366 & 54 & Хлебодарка & Украина & 26,84 & 730 & 10 & 11,7 & 3,5 & 8,2 & 75 & 10 & 0 & 0 & 100 & 1,5 & 75 & 0 \\
\hline 374 & 67 & Зірница & Украина & 33,54 & 730 & 10 & 15,8 & 3,8 & 12 & 0 & 0 & 25 & 4 & 16 & 1 & 0 & 1 \\
\hline 392 & 15 & Василина & Украина & 34,07 & 734 & 7 & 6,1 & 3,7 & 2,4 & 100 & 1 & 0 & 0 & 100 & 1 & 0 & 0 \\
\hline 440 & 130 & $\begin{array}{c}\text { Мироновская } \\
31\end{array}$ & Украина & 43,24 & 736 & 4 & 9,6 & 6,8 & 2,8 & 60 & 0,6 & 0 & 0 & 0 & 0 & 20 & 1 \\
\hline 450 & 177 & $\begin{array}{c}\text { Мироновская } \\
32 \\
\end{array}$ & Украина & 37 & 0 & 6 & 9,7 & 5 & 4,7 & 75 & 2,5 & 0 & 0 & 0 & 0 & 100 & 0 \\
\hline 469 & 87 & $\begin{array}{c}\text { Мироновская } \\
63\end{array}$ & Украина & 30,86 & 741 & 5 & 9,2 & 6,4 & 2,8 & 0 & 0 & 0 & 0 & 0 & 0 & 100 & 1 \\
\hline 471 & 95 & $\begin{array}{c}\text { Мироновская } \\
33\end{array}$ & Украина & 45,66 & 760 & 6 & 4,5 & 3 & 1,5 & 0 & 0 & 0 & 0 & 100 & 0,5 & 0 & 1 \\
\hline 474 & 41 & $\begin{array}{c}\text { Мироновская } \\
64\end{array}$ & Украина & 51,05 & 778 & 7 & 7 & 5,1 & 1,9 & 50 & 1,3 & 0 & 0 & 75 & 1 & 0 & 1 \\
\hline 475 & 59 & $\begin{array}{c}\text { Мироновская } \\
34\end{array}$ & Украина & 40,75 & 740 & 10 & 5,7 & 3,2 & 2,5 & 50 & 1 & 0 & 0 & 50 & 0 & 0 & 0 \\
\hline 520 & 57 & Pitko (Jo 3063) & финляндия & 18,33 & 0 & 6 & 17,5 & 9,3 & 8,2 & 50 & 5 & 0 & 0 & 16 & 0,2 & 0 & 0 \\
\hline 319 & 71 & Brigadier & Франция & 0 & 754 & 5 & 8,8 & 4,8 & 4 & 75 & 5 & 0 & 0 & 25 & 1 & 0 & 1 \\
\hline 345 & 48 & Amelio & Франция & 30,37 & 746 & 10 & 7,6 & 2,9 & 4,7 & 100 & 12,5 & 0 & 0 & 100 & 0 & 0 & 0 \\
\hline 346 & 80 & Famulus & Франция & 31,75 & 714 & 4 & 7,4 & 5 & 2,4 & 50 & 0 & 0 & 0 & 50 & 1,8 & 75 & 0 \\
\hline 368 & 52 & Choc & Франция & 34,7 & 744 & 10 & 7 & 3,5 & 3,5 & 100 & 5 & 0 & 0 & 50 & 0 & 0 & 0 \\
\hline 405 & 39 & Louvre & Франция & 32,8 & 723 & 8 & 5,9 & 3,3 & 2,6 & 75 & 1 & 0 & 0 & 50 & 1 & 0 & 1 \\
\hline 424 & 129 & Alcan & Франция & 36,11 & 748 & 4 & 7,75 & 4,25 & 3,5 & 25 & 0,25 & 0 & 0 & 0 & 0 & 50 & 1 \\
\hline 442 & 9 & Logor & Франция & 0 & 763 & 5 & 15 & 11,8 & 3,2 & 0 & 0 & 0 & 0 & 0 & 0 & 100 & 0 \\
\hline 462 & 40 & Garmil & Франция & 0 & 690 & 4 & 7,5 & 4 & 3,5 & 0 & 0 & 0 & 0 & 25 & 1 & 100 & 0 \\
\hline 484 & 38 & Rafale & Франция & 0 & 0 & 10 & 5,9 & 2,1 & 3,8 & 75 & 8,8 & 0 & 0 & 0 & 0 & 0 & 0 \\
\hline 543 & 46 & Coquelles & Франция & 12 & 672 & 5 & 12,4 & 7,2 & 5,2 & 50 & 5 & 0 & 0 & 0 & 0 & 0 & 1 \\
\hline 306 & 98 & Samanta & Чехия & 33,28 & 742 & 4 & 14,5 & 7 & 7,5 & 83 & 1,7 & 32 & 2,6 & 32 & 0,33 & 16 & 0 \\
\hline 376 & 101 & Saskia & Чехия & 0 & 719 & 6 & 12 & 4,5 & 7,5 & 83 & 2,7 & 0 & 0 & 16 & 0 & 16 & 0 \\
\hline 423 & 103 & Sarka & Чехия & 26,38 & 712 & 10 & 5,1 & 3,4 & 1,7 & 83 & 2,6 & 32 & 1,7 & 16 & 0,2 & 32 & 1 \\
\hline 473 & 42 & Samanta & पехия & 30,39 & 712 & 4 & 7,8 & 2,5 & 5,3 & 100 & 3 & 0 & 0 & 50 & 0,2 & 25 & 1 \\
\hline 522 & 100 & Sofia & Чехия & 0 & 0 & 7 & 9,8 & 5,4 & 4,4 & 32 & 0,7 & 0 & 0 & 0 & 0 & 0 & 0 \\
\hline 545 & 118 & Livia & Чехия & 0 & 0 & 2 & 10,5 & 7 & 3,5 & 75 & 3,75 & 0 & 0 & 0 & 0 & 50 & 1 \\
\hline 554 & 173 & Samara & Чехия & 0 & 0 & 5 & 9,2 & 3,8 & 5,4 & 50 & 1 & 0 & 0 & 25 & 0 & 100 & 0 \\
\hline 321 & 160 & $\begin{array}{c}\text { Мироновская } \\
5 / 5\end{array}$ & Эстония & 24,07 & 724 & 4 & 6,25 & 5,5 & 0,75 & 100 & 5 & 0 & 0 & 0 & 0 & 0 & 1 \\
\hline 529 & 144 & Satsukei 131 & Япония & 0 & 0 & 7 & 8,8 & 4,7 & 4,1 & 75 & 1 & 0 & 0 & 75 & 0,75 & 25 & 0 \\
\hline
\end{tabular}


Выполнение исследований стало возможным благодаря помощи активных участников студенческого научного общества «Агроэкотест» Оренбургского ГАУ, среди которых необходимо отметить Воденникова Д.Г., Савченко Д.Г., Лимова Д.Б., Каширина Д.С., Плотникова А.С., Шепелева А.Н., Носову Е.Н., Игнатьева А И., Морозова Е.В., Орлова А.В., Тыщенко Т.В. и Шишкову А.П.

\section{БИБЛИОГРАФИЯ}

[1] Оренбургская область увеличит озимый клин на 50\%. Режим доступа: http://www.agro-forum.info/blog/?p=1094

[2] Назарова Л.Н., Полякова Т.М., Жохова Т.П. и др. Фитосанитарное состояние посевов пшеницы в России в 2006-2010 гг./Назарова Л.Н., Полякова Т.М., Жохова Т.П., Корнева Л.Г.// Защита и карантин растений. 2012. № 6. С. 39-42.

[3] А.П. Глинушкин, О.О. Белошапкина, С.В. Виноградова, и др. Диагностика вирусных симптомов у сортообразцов озимой пшеницы из коллекции ВНИИР / А.П. Глинушкин, О.О. Белошапкина, С.В. Виноградова, Н.А. Николаев// Достижения науки и техники АПК. №2. - 2013. С. 24-27.

[4] А.П. Глинушкин, Ю.А. Кошеваров, А.А. Соловых, и др. Мониторинг микозов пшеницы в условиях степной зоны Южного Урала/ А.П. Глинушкин, Ю.А. Кошеваров, А.А. Соловых, А.А. Райов, Л.Н. Хилько// Вестник Орловского ГАУ. 2013. - №1. - C. 54-58.

[5] DuPont Pioneer is the market leader in the soft winter wheat region of the United States //www.pioneer.com/home/site/about/products/crops/wheat (дата обращения: 02.01.2013).

[6] Жученко А.А. Стратегия адаптивной интенсификации сельского хозяйства. Концепция. Пущино, 1994, 174 с.

[7] Шпаар Д. (Ред.) Защита растений в устойчивых системах землепользования (в четырех книгах), Берлин, 2001, книга 1, 312 с.; книга 2, 380 с.

[8] Diereks R., Heitefuss R. (Hrsg) Integrierter Landbau. 2 Aufl. DLG-Verlag FrankfurtMain. 1995, $440 \mathrm{~s}$.

[9] Глинушкин А.П., Соловых А.А., Лукъянцев В.С. и др. Одна технология - два вида защиты / Глинушкин А.П., Соловых А.А., Лукъянцев В.С., Душкин С.А., Сударенков Г.В.// Russian Journal of Agricultural and Socio-Economic Sciens 2012, №3. URL: http:// www.rjoas.com/issue-2012-03/i003_article_2012_01.pdf (дата обращения: 05.02.2013).

[10] Глинушкин А.П. Пшеница и хлеб: агроэкологическая и технологическая эффрективность защиты яровой пшеницы в условиях степной зоны Южного Урала. Саратов: ИЦ «Наука», 2009. - 198 с. 